\title{
ANALISA PENGARUH MOTIVASI KERJA TERHADAP PRESTASI KERJA DOSEN PADA SEKOLAH TINGGI ILMU EKONOMI AAS
}

\author{
Dra. Wikan Budi Utami, MM \\ STIE - AAS Surakarta \\ Email: wikan.budiutami@yahoo.com
}

\begin{abstract}
Abstrak
The purpose of this study is to determine the relationship between work motivation with the performance of lecturer at the College of Economics AAS (STIE-AAS). The motivation factor used in this research is based on the five human needs according to Maslow, namely physiological needs, safety needs, social needs, self-esteem needs, and self-actualization needs. The population in this study are lecturers STIE-AAS who actively teach at the time this research is done. This research was conducted in the even semester of academic year 2015/2016 in March-April 2016. The technique of determining the sample in this study is to use purposive sampling. The sample in this research is: STIE-AAS lecturer who in the even semester of Academic Year 2015/2016 actively teaches. The type of instrument used in this study, namely questionnaires. To test whether the list of questionnaires that are made, valid (valid) and reliable (reliable) then used two test tools of the test validity and reliability test. This t test is used to examine the influence of each independent variable (physiological needs, safety needs, social needs, self-esteem needs, and self-actualization needs) to the dependent variable (STIE-AAS lecturer work achievement). The statistical test F aims to examine the effects of all independent or independent variables (physiological needs, safety needs, social needs, self-esteem needs, and self-actualization needs) together with dependent or dependent variables (STIE-AAS lecturer work achievement). This test is done by SPSS 17. Test R2 (Coefficient of determination) is done to find out how much influence the variable of physiological needs, the need of sense of security, social needs, self-esteem needs, and self-actualization needs towards the work performance variable of STIE-AAS lecturer. From the result of $t$ test, it is known that the need for security and self-esteem need to be partially significant to the performance of STIE-AAS lecturers. While the physiological needs, social needs and self-actualization needs no significant effect on the performance of lecturers STIE-AAS. From the results of F test, it is known that physiological needs, safety needs, social needs, self-esteem needs, and self-actualization needs simultaneously have a significant effect on the performance of STIE-AAS lecturers. From result of test of R2 obtained coefficient value of determination equal to 0,639 which mean $63,9 \%$ achievement of lecturer work influenced by factors which resear in this research.
\end{abstract}

Keywords: physiological needs, safety needs, social needs, self-esteem needs, self-actualization needs and work performance of STIE-AAS lecturers.

\section{Pendahuluan}

Dosen memegang peranan penting dalam mencapai prestasi akademik mahasiswa. Untuk mencapai hal tersebut dosen diharapkan mampu meningkatkan kompetensi profesionalnya karena hal tersebut merupakan salah satu tolok ukur prestasi kerja dosen Organisasi pendidikan yang ingin JURNAL ILMIAH EKONOMI ISLAM, ISSN: 2477-6157 ; E-ISSN 2579-6534 berhasil harus memiliki sumber daya manusia yang unggul dan mampu bekerja secara profsional. Untuk mencapai prestasi kerja yang tinggi, individu-individu perlu dimotivasi. Pimpinan beserta jajaran manajemen merupakan pihak yang berperan penting bagi pengembangan dan peningkatan prestasi kerja dosen. Untuk mencapai organisasi pendidikan 
yang berkualitas diperlukan pimpinan yang baik, mampu mengelola dan mengarahkan dosen dan tenaga kependidikan dalam mencapai tujuan organisasi.Pengelolaan ini tidak sekedar mengetahui kemampuan dosen dalam melaksanakan kegiatan pendidikan, penelitian dan pengabdian, lebih dari itu diperlukan pimpinan yang mampu memotivasi dosen agar membantu tercapainya visi dan misi STIE-AAS tercapai.

Motivasi yang tinggi akan memberikan konstribusi yang baik terhadap kinerja organisasi. Dengan demikian motivasi kerja merupakan faktor yang penting karena berhubungan dengan tingkat prestasi kerja dosen yang selanjutnya akan meningkatkan efektifitas pengelolaan pendidikan sehingga diperoleh lulusan dengan indeks prestasi yang diharapkan.

\section{Rumusan Masalah}

1. Apakah motivasi kerja yaitu kebutuhan fisiologis, kebutuhan rasa aman, kebutuhan sosial, kebutuhan harga diri,dan kebutuhan aktualisasi diri berpengaruh terhadap prestasi kerja dosen STIE-AAS secara parsial.

2. Apakah motivasi kerja yaitu kebutuhan fisiologis, kebutuhan rasa aman, kebutuhan sosial, kebutuhan harga diri,dan kebutuhan aktualisasi diri berpengaruh terhadap prestasi kerja dosen STIE-AAS secara simultan.

3. Faktor motivasi apakah yang mempunyai pengaruh paling kuat terhadap prestasi kerja dosen STIE AAS.

\section{Tujuan Penelitian}

1. Untuk mengetahui apakah motivasi kerja yaitu kebutuhan fisiologis, kebutuhan rasa aman, kebutuhan sosial, kebutuhan harga diri,dan kebutuhan aktualisasi diri berpengaruh terhadap prestasi kerja dosen STIE-AAS secara parsial

2. Untuk mengetahui apakah apakah motivasi kerja yaitu kebutuhan fisiologis, kebutuhan rasa aman, kebutuhan sosial, kebutuhan harga diri,dan kebutuhan aktualisasi diri berpengaruh terhadap prestasi kerja dosen STIE-AAS secara simultan

3. Untuk mengetahui faktor motivasi apakah yang mempunyai pengaruh paling kuat terhadap prestasi kerja dosen STIE AAS.

\section{Landasan Teori}

1. Motivasi

Istilah motivasi sering digunakan secara bergantian dengan istilah kebutuhan (need), keinginan (want), dorongan (drive), dan gerak hati (impuls). Hersey dan Blanchard (1989) menyatakan istlah-istilah tersebut merupakan motif. Sedangkan motivasi adalah kekuatan yang mendorong seseorang untuk melakukan suatu kegiatan. Motif masih bersifat potensial, dan aktualisasinya dinamakan motivasi. Serta pada umumnya diwujudkan dalam bentuk perbuatan nyata. Menurut Maslow (1970) motivasi adalah tenaga pendorong dari dalam yang menyebabkan manusia berbuat sesuatu atau berusaha untuk memenuhi kebutuhannya. Dalam penelitian ini yang dimaksud dengan motivasi adalah keinginan yang menggerakkan atau yang mendorong seseorang atau diri sendiri untuk berbuat sesuatu. Berdasarkan teori motivasi diketahui bahwa perilaku itu tidak terjadi dengan sendirinya, melainkan ada yang mendorong. pernyataan ini dapat dipahami dengan mendefinisikan motivasi atau dorongan sebagai suatu keinginan yang kuat untuk mencapai tujuan organisasi berlandaskan kemampuan usaha tersebut guna memenuhi kebutuhan (Robbins, 1993). 
Jewel dan Siegal (1998) mengatakan bahwa masalah praktis dari motivasi menjadi perhatian baik para psikolog industri/organisasi maupun para manajer. Mereka mengetahui bahwa pengertian mengenai kekuatan yang menghasilkan, mengarahkan dan mempertahankan usaha.

Beberapa ahli teori yakin bahwa kekuatan ini terdapat di dalam (internal), dikendalikan oleh kebutuhan dasar manusia. Secara kelompok, gagasan mereka dinamakan teori kebutuhan dari motivasi kerja. Para ahli dalam (dalam Supriyanto dkk 2003) mengelompokkan teori motivasi ke dalam kategori utama yaitu: pertama, teori isi (Content Theory) dan kedua, teoriproses (Process Theory). Keduanya dapat dijelaskan sebagai berikut:

Pertama, teori isi (Content Theory) yaitu memusatkan perhatian pada faktor-faktor di dalam diri orang yang menggerakkan, mengarahkan, mendukung, dan menghentikan perilaku. Teori isi (Content Theory) bermaksud unuk menentukan apa yang memotivasi orang dalam pekerjaan mereka. Teori ini mencoba menentukan kebutuhan khusus yang memotivasi orang. Pada permulaannya banyak ahli berpendapat hanya uang yang memotivasi mereka (manajemen ilmiah), dan kemudian dirasa juga kondisi kerja, keamanan, dan barang kali gaya supervise demokratis (hubungan manusia). Lebih lanjut teori isi telah dipandang lebih dalam lagi dan dikenal sebagai motif-motif dengan "tingkatan lebih tinggi”. Tiga model teori isi meliputi: teori hirarki kebutuhan Maslow, teori ERG dari Clayton Aldefer, teori Harzberg, dan teori kebutuhan dari David Me Clelland. Kedua, teori proses (Process Theory) mencoba menguraikan dan menganalisis bagaimana perilaku itu digerakkan, diarahkan, didukung dan dihentikan. Yang termasuk dalam kategori proses adalah: Teori Harapan VictorVroom, Teori Penguatan B.F. Skinner, Teori keadilan Adams dan teori Penetapan Tujuan Locke.

Dalam pembahasan ini akan lebih ditekankan pada teori isi (content Theory) dari Teori Hirarki Kebutuhan Maslow. Abraham Harold Maslow dilahirkan dari keluarga imigran Yahudi-Rusia di Brooklyn, New York, pada 1 April 1908. Dan meninggal pada tahun 1970. Maslow merupakan salah satu tokoh utama dalamaliran psikologi humanistic yang lahir di Amerika decade 1950-an. Salah satu teori Maslow yang paling popular adalah teori kebutuhan bertingkat, sehingga dikenal dengan teori hirarki kebutuhan Maslow. Menurut teori ini, kebutuhan manusia bermacam-macam dan dapat dikelompokkelompokkan. Adapun ide yang ingin dilontarkan oleh Abraham Maslow adalah bahwa kebutuhan manusia yang beraneka ragam tersebut dapat dikelompokkan ke dalam lima kelompok menurut urut-urutan kepentingannya, sebagai berikut: 
a. Kebutuhan-kebutuhan Fisiologis (Physiological Needs)

Kebutuhan-kebutuhan fisiologis adalah sekumpulan kebutuhan dasar yang paling mendesak pemuasannya karena berkaitan langsung dengan pemuasan biologis dan kelangsungan hidup. Kebutuhan-kebutuhan dasar fisiologis itu antara lain kebutuhan akan makan, air, oksigen, aktif, istirahat, keseimbangan temperature, seks, dan kebutuhan akan stimulasi sensoris. Karena merupakan kebutuhan yang paling mendesak, maka kebutuhankebutuhan fisiologis akan paling didahulukan pemuasannya oleh individu. Dan jika kebutuhan fisiologis ini tidak terpenuhi atau belum terpuaskan, maka individu tidak akan tergerak untuk bertindak memuaskan kebutuhankebutuhan kain yang lebih tinggi. Sebagi contoh, jika kita sedang lapar maka kita tidak akan bergerak untuk belajar, membuat komposisi music atau membangun sesuatu. Pada saat lapar kita dikuasai oleh hasrat untuk memperoleh makanan secepatnya (Koswara, 1991)

Dengan demikian tidak bisa dipungkiri lagi bahwa kepuasan fisiologis itu merupakan pendorong dan member pengaruh yang kuat atas tingkah laku manusia, dan manusia akan selalu berusaha memuaskannya sebelum memuaskan kebutuhan-kebutuhan lain yang lebih tinggi.

b. Kebutuhan Akan Rasa Aman (need For Self-Securitay)

Apabila kebutuhan fisiologis individu telah terpusatkan, maka dalam diri individu akan muncul sutu kebutuhan yang dominan dan menuntut pemuasan, yakni kebutuhan akan rasa aman (need for self-security). Yang dimaksud oleh Maslow (dalam Koswara, 1990) dengan kebutuhan rasa aman ini adalah suatu kebutuhan yang mendorong individu yang memperoleh ketentraman, kepastian, dan keteraturan dari keadaan lingkungannya. Contoh paling nyata bahwa manusia sangat membutuhkan rasa aman adalah pada saat masa bayi dan anak-anak yang membutuhkan perlindungan dari orang tuanya. Pada orang dewasa pun kebutuhan akan rasa aman ini Nampak dan berpengaruh secara aktif. Usaha-usaha untukmemperoleh perlindungan dan keselamatan kerja, penghasilan tetap atau membayar asuransi,merupakan contoh-contoh dari tingkah laku yang mencerminkan kebutuhan akan rasa aman pada orang-orang dewasa. Untuk sebagian, system-sistem kepercayaan agama dan filsafat bias ditafsirkan demikian. Agama dan filsafat oleh sementara orang dianggap sebagai alat yang bias membantu mereka untuk mengorganisasikan dunianya. Maslow (1970) selanjutnya menyatakan, bahwa tipe dari keadaan neurotic, yakni obsesikompulasi, terutama didorang oleh pencarian rasa aman. Sejumlah orang neurotic, apabila menghadapi keadaan tertentu melalui penampilan yang rapi, berdisiplin, dan teratur. Kebutuhan akan rasa aman dari orang-orang neurotic itu juga sering diekspresikan melalui keinginan mencari pelindung atau orangorang kuat yang hisa dijadikan bergantung.

c. Kebutuhan Akan Cinta dan Rasa Memiliki (Need For Love And Belongingness) 
Kebutuhan akan cinta dan rasa, (need for love and belongingness) ini adalah suatu kebutuhan yang mendorong individu untuk mengadakan hubungan efektif atau ikatan emosional dengan individu lain, baik dengan sesama jenis maupun dengan yang berlainan jenis, di lingkungan keluarga ataupun di lingkungan kelompok di masyarakat. Bagi individu-individu, keanggotaan dalam kelompok sering menjadi tujuan yang dominan, dan mereka bisa menderita kesepian, terasing, dan tak berdaya apabila keluarga, pasangan hidup, rekan kerja, atau teman-teman meninggalkannya. Maslow dengan tegas menolak pendapat Freud bahwa cinta dan afeksi itu berasal dari naluri seksual yang disublimasi. Bagi Maslow, cinta dan seks adalah dua hal yang sama sekali berbeda. Selanjutnya Maslow menegaskan bahwa cinta yang matang menunjuk kepada hubungan cinta yang sehat di antara dua orang atau lebih, yang di dalamnya terdapat sikap saling percaya dan saling menghargai. Maslow juga menekankan bahwa kebutuhan akan cinta itu mencakup keinginan untuk mencintai dan mencintai. Mencintai dan dicintai menurut Maslow, merupakan prasyarat bagi adanya perasaan yang sehat. Sebalikya, tanpa cinta orang akan dikuasai oleh perasaan kebencian, rasa tak barharga dan kehampaan. Maslow akhirnya menyimpulkan, bahwa antara kepuasan cinta efeksi di masa kanakkanak dan kesehatan mental di masa dewasa terdapat korelasi yang signifikan. (Koswara, 1991)

\section{d. Kebutuhan akan harga diri (Need For} Self- Esteem)
Kebutuhan yang keempat, yakni kebutuhan akan rasa harga diri (need for self-esteem), oleh Maslow dibagi ke dalam dua bagian. Bagian pertama adalah penghormatan dan penghargaan diri sendiri, dan bagian kedua adalah peng-hargaan dari orang lain. Bagian pertama mencakup hasrat untuk memperoleh kompetensi, rasa percaya diri, kekuatan pribadi, adekuasi, kemandirian, dan kebe-basan. Individu ingin mengetahui atau yakin bahwa dirinya berharga serta mampu mengatasi segala tantangan dalam hidupnya. Adapun bagian yang kedua meliputi antara lain prestasi. Dalam hal ini butuh penghargaan atas apa-apa yang dilakukannya. Terpuaskannya akan kebutuhan akan rasa harga diri pada individu akan menghasilkan sikap percaya diri, rasa berharga, rasa takut, rasa mampu, dan rasa perasaan berguna. Sebaliknya, frustasi atau terlambatnya pemuasan kebutuhan akan rasa harga diri itu akan menghasilkan sikap rendah diri, rasa tidak pantas, rasa lemah, rasa tak mampu, dan rasa tak berguna, yang menyebabkan individu tersebut mengalami kehampaan, keraguan, dan keputusasaan dalam menghadapi tuntutan hidupnya, serta memiliki penilaian yang rendah atas dirinya sendiri dalam kaitannya dengan orang lain. Maslow menegaskan bahwa rasa harga diri yang sehat lebih di dasarkan pada prestasi ketimbang prestise, status, atau kerun-tuhan. Dengan perkataan lain, rasa harga diri individu yang sehat adalah hasil usaha individu yang bersangkutan. Dan merupakan bahaya psikologis yang nyata apabila seseorang lebih mengandalkan rasa harga dirinya 
pada opini orang lain ketimbang pada kemampuan dan prestasi nyata dirinya sendiri (Koswara, 199)

\section{e. Kebutuhan Akan Aktualisasi Diri (Need For Self-Actualization)}

Kebutuhan untuk mengungkapkan diri atau aktualisasi diri (need for self actualization) merupakan kebutuhan manusia yang paling tinggi dalam teori Maslow. Kebutuhan ini akan muncul apabila kebutuhan-kebutuhan yang ada di bawahnya telah terpuaskan dengan baik. Maslow menandai kebutuhan akan aktu-alisasi diri sebagai hasrat individu untuk menjadi orang yang sesuai dengan keinginan dan potensi yang dimilikinya. Contoh dari aktualisasi diri ini adalah seseorang yang berbakat music menciptakan komposisi music, seseorang yang me-miliki potensi intelektual menjadi ilmuan, dan seterusnya.

Maslow mencatat bahwa aktualisasi diri itu tidak hanya berupa mencip-takan kreasi atau karya-karya berdasarkan bakat-bakat atau kemampuan-kemampuan khusus. Orang tua, mahasiswa, dosen, pegawai, dan buruh pun bias mengak-tualisasikan dirinya, yakni dengan jalan membuat yang terbaik, atau bekerja sebaik-baiknya sesuai dengan bidangnya masing-masing. Bentuk aktualisasi diri ini berbeda pada setiap orang. Hal ini tidak lain disebabkan dan merupakan cerminan dari adanya perbedaan-perbedaan individual. Bagaimanapun, Maslow mengakui bahwa untuk mencapai taraf aktualisasi diri atau memenuhi kebutuhan akan aktu-alisasi diri tidaklah mudah, sebab upaya kearah itu banyak sekali hambatannya. Menurut Maslow, paling tidak ada tiga hambatan apabila individu ingin mengaktualisasikan dirinya. Pertama, hambatan dari dalam diri individu, yakni berupa ketidaktahuan, keraguan, dan bahkan juga rasa takut dari individu untuk mengungkapkan potensi-potensi yang dimilikinya, sehingga potensi-potensi itu tetap laten. Kedua, hambatan yang berasal dari luar atau dari masyarakat. Hambatan dari masyarakat ini dapat berupa kecenderungan mendepersonalisasi individu, juga berupa perepresian sifatsifat, bakat, atau potensi-potensi. Masyarakat sering merepres pengungkapkan sifat-sifat, atau kebiasaan-kebiasaan yang spesifik dari para warganya yang, apabila terungkap, bisa mengantarkan mereka menuju aktualisasi diri. Tegasnya, aktualisasi diri itu hanya mungkin apabila kondisi lingkungan menunjangnya. Kenyataannya menurut keyakinan Maslow, tidak ada satu-pun lingkungan masyarakat yang sepenuhnya menunjang atas upaya aktualisasi diri para warganya, meski tentunya ada beberapa masyarakat yang jauh lebih baik dan menunjang daripada masyarakat yang lainnya Selanjutnya Maslow juga berpendapat bahwa perilaku karyawan hanya akan dipengaruhi oleh kebutuhan yang belum terpuaskan. Dengan kata lain, jika suatu kebutuhan secara relative sudah dapat terpuaskan, maka ia akan mencoba untuk memuaskan kebutuhan yang lebih tinggi berikutnya. Oleh karena itu pemberian penghargaan akan efisien apabila pihak lembaga dapat memahami 
kebutuhan yang belum terpenuhi dan memberikannya

Motivasi mempunyai hubungan positif terhadap prestasi kerja. "Motivasi kerja adalah sesuatu yang menimbulkan semangat atau dorongan kerja. Kuat lemahnya motivasi kerja seseorang karyawan ikut menentukan besar kecilnya prestasi kerja." (As'ad, 1995:45)

Menurut pendapat Mc Clleland yang dikutip oleh Malayu S.P Hasibuan (2002;162) yang menyatakan bahwa : "Motivasi akan mendorong seseorang untuk mengembangkan kreativitas dan mengerahkan semua kemampuan serta energi yang dimilikinya demi mencapai prestasi kerja yang maksimal”.

Berdasarkan teori Maslow ini maka dosen secara individual maupun Perguruan Tinggi dapat meningkatkan kinerja dosen apabila mengetahui kebutuhan-kebutuhan yang mendesak dibutuhkan oleh masing-masing dosen maupun organisasi dan berusaha untuk memenuhi kebutuhan yang lebih tinggi.

\section{Prestasi Kerja}

\section{a. Pengertian Prestasi Kerja}

Pengertian prestasi kerja disebut juga sebagai kinerja atau dalam bahasa Inggris disebut dengan performance. Pada prinsipnya, ada istilah lain yang lebih menggambarkan pada "prestasi" dalam bahasa Inggris yaitu kata "achievement". Tetapi karena kata tersebut berasal dari kata "to achieve" yang berarti "mencapai", maka dalam bahasa Indonesia sering diartikan menjadi "pencapaian" atau "apa yang dicapai”. (Ruky, 2002:15)

Bernardin dan Russel (1993:378) memberikan definisi tentang prestasi kerja sebagai berikut : "performance is defined as the record of outcome produced on a specified job function or activity during a specified time period" (Prestasi kerja didefinisikan sebagai catatan dari hasil-hasil yang diperoleh melalui fungsi-fungsi pekerjaan tertentu atau kegiatan selama tempo waktu tertentu).

Menurut Malayu S.P.Hasibuan (2000;93) mengemukakan bahwa :

"Prestasi kerja adalah suatu hasil kerja yang dicapai seseorang dalam melaksanakan tugas-tugas yang dibebankan kepadanya atas dasar kecakapan, pengalaman, dan kesungguhan serta waktu. Prestasi kerja merupakan gabungan dari 3 faktor penting, yaitu kemampuan dan minat seorang pekerja, kemampuan dan penerimaan atas penyelesaian delegasi tugas, serta peran dan tingkat motivasi xseorang pekerja. Semakin tinggi ketiga factor diatas, semakin besarlah prestasi kerja karyawan yang bersangkutan".

Pengertian diatas sejalan dengan pendapat Keith Davis, yang dikutip oleh

A.A. Anwar Prabu Mangkunegara (2000;67) yang merumuskan bahwa :

1. Human Performance = Ability + Motivation

2. Motivation

Atitude + Situation

3. Ability

Knowledge + Skill

Masih menurut A.A Anwar Prabu Mangkunegara (2000;67), isitilah prestasi kerja berasal dari Job performance atau Actual performance. Pengertian prestasi kerja (kinerja) adalah hasil kerja secara kualitas dan kuantitas yang dicapai oleh seorang pegawai dalam melaksanakan tugasnya sesuai 
dengan tanggung jawab yang diberikan kepadanya.

Adapun indikator mengenai prestasi kerja menurut A.A Anwar Prabu Mangkunegara $\quad(2002 ; 67) \quad$ sebagai berikut :

1. Kualitas kerja

2. Kuantitas kerja

3. Konsistensi pegawai

4. Kerjasama

5. Sikap pegawai

Berdasarkan pendapat para ahli diatas, penulis dapat menyimpulkan bahwa prestasi kerja adalah segala sesuatu yang dihasilkan oleh karyawan melalui pencurahan segenap kemampuan dan potensi serta totalitas yang dimilikinya untuk mencapai tujuan yang telah ditentukan.

b. Faktor-faktor Yang mempengaruhi Prestasi Kerja

\section{1) Faktor Kemampuan}

Secara psikologis, kemampuan (ability) pegawai terdiri dari kemampuan potensi (IQ) dan kemampuan reality (knowledge + skill). Artinya, pegawai atau karyawan yang memiliki IQ diatas rata- rata (IQ 110-120) dengan pendidikan yang memadai untuk jabatannya dan terampil dalam mengerjakan pekerjaanya, maka ia akan lebih mudah mencapai prestasi kerja yang diharapkan. Oleh karena itu, pegawai perlu ditempatkan pada pekerjaan yang sesuai dengan kemampuannya (the right man on the right place, the right man on the right job).

\section{2) Faktor Motivasi}

Motivasi terbentuk dari sikap (attitude) seorang pegawai dalam menghadapai situasi (situation) kerja. Motivasi merupakan kondisi yang menggerakan diri pegawai yang terarah untuk mencapai tujuan organisasi (tujuan kerja).

Sikap mental merupakan kondisi mental yang mendorong diri pegawai untuk berusaha mencapai prestasi kerja secara maksimal. Sikap mental seorang pegawai harus siap secara psikofisik (siap mental, fisik, tujuan dan situasi). Artinya, seorang pegawai harus mampu secara mental, mampu secara fisik, memahami tujuan utama, dan target kerja yang akan dicapai serta mampu memanfaatkan dan menciptakan situasi kerja.

\section{c. Hubungan Motivasi Kerja dengan} Prestasi Kerja Karyawan

Hubungan antara motivasi kerja dengan prestasi kerja secara sederhana dapat dikemukakan sebagai berikut. Setiap perusahaan mengharapkan adanya tingkat prestasi kerja yang tinggi dan terus menerus dari para karyawannya. Oleh karena itu, pihak perusahaan harus senantiasa bisa melakukan suatu metode dorongan atau rangsangan terhadap para karyawannya agar mau bekerja secara efektif dan efisien.

Banyak faktor yang dapat mempengaruhi peningkatan prestasi kerja karyawan, diantaranya adalah Motives. Motivasi berarti membangkitkan daya gerak atau menggerakan seseorang atau diri sendiri untuk mencapai suatu tujuan. Dengan mengetahui tujuan seseorang atau perusahaan, maka relatif mudah untuk mngetahui seseorang atau perusahaan 
untuk melaksanakan tindakan- tindakan dalam rangka pemuasan kebutuhan.

Motivasi mempunyai hubungan positif terhadap prestasi kerja. "Motivasi kerja adalah sesuatu yang menimbulkan semangat atau dorongan kerja. Kuat lemahnya motivasi kerja seseorang karyawan ikut menentukan besar kecilnya prestasi kerja." (As'ad, 1995:45)

Menurut pendapat Mc Clleland yang dikutip oleh Malayu S.P Hasibuan (2002;162) yang menyatakan bahwa : "Motivasi akan mendorong seseorang untuk mengembangkan kreativitas dan mengerahkan semua kemampuan serta energi yang dimilikinya demi mencapai prestasi kerja yang maksimal".

Menurut Kae Chung \& Megginson yang dikutip oleh Faustino Cardoso Gomes $(2002 ; 177)$ menyatakan hubungan antara motivasi kerja dengan prestasi kerja :

"Motivation is defined as goaldirected behaviour. It concerns the level of effort one exerts in pursuing a goal.... It is closely related to employee satisfaction and job performance."

(Motivasi dirumuskan sebagai perilaku yang ditujukan pada sasaran. Motivasi berkaitan dengan tingkat usaha yang dilakukan oleh seseorang dalam mengejar suatu tujuan. Motivasi berkaitan erat dengan kepuasan pekerja dan performansi pekerjaan / prestasi kerja). Berdasarkan penelitian Mc. Clelland (1961), Edward Murray (1957) dan Gordon W (1970) yang dikutip oleh A.A Anwar Prabu Mangkunegara (2000;104), menyimpulkan bahwa ada hubungan yang positif antara motivasi berprestasi dengan pencapaian prestasi kerja.

Melihat hasil penelitian yang dilakukan oleh para ahli, dapat disimpulkan bahwa hubungan antara motivasi kerja dengan prestasi kerja bahwa didalamnya terdapat pengaruh yang erat dan tidak dapat dipisahkan antara satu dan yang lainnya.

\section{Penelitian Terdahulu}

Penelitian yang akan dilakukan didasarkan atas penelitian - penelitian terdahulu, yaitu:

Pertama, penelitian yang dilakukan oleh Rusdiyanto (2012) yang meneliti tentang pengaruh motivasi terhadap prestasi kerja pegawai di satuan polisi pamong praja Kabupaten Tulungagung. Ada 6 variabel independen yang digunakan dalam penelitian tersebut yaitu: gaji, kepuasan kerja, kondisi kerja, kerjasama, kesempatan untuk maju dan kebijakan organisasi.

Kedua penelitian yang dilakukan oleh Theodora Yatipai, John Montolalu dan Sonny Gerson Kaparang (2015). Hasil penelitian tersebut adalah motivasi berpengaruh signifikan terhadap prestasi kerja karyawan pada PT Kantor Pos Tipe C.

Ketiga penelitian yang dilakukan oleh Sindi Larasati (2014) yang meneliti tentang pengaruh motivasi kerja terhadap kinerja karyawan Wilayah Telkom Jabar Barat Utara (Witel Bekasi). Ada 3 variabel independen yang digunakan dalam penelitian tersebut yaitu: kebutuhan prestasi, kebutuhan afiliasi dan kebutuhan kekuasaan.

Keempat penelitian yang dilakukan oleh Puguh Dwi Cahyono yang meneliti tentang pengaruh motivasi terhadap prestasi kerja karyawan (studi pada karyawan AJB Bumi Putera 1912 Cabang Kayutangan Malang). 
Variabel independen yang digunakan ada 3

berhubungan, kebutuhan berkembang. yaitu: kebutuhan eksistensi, kebutuhan

\section{Kerangka Pemikiran Penelitian}

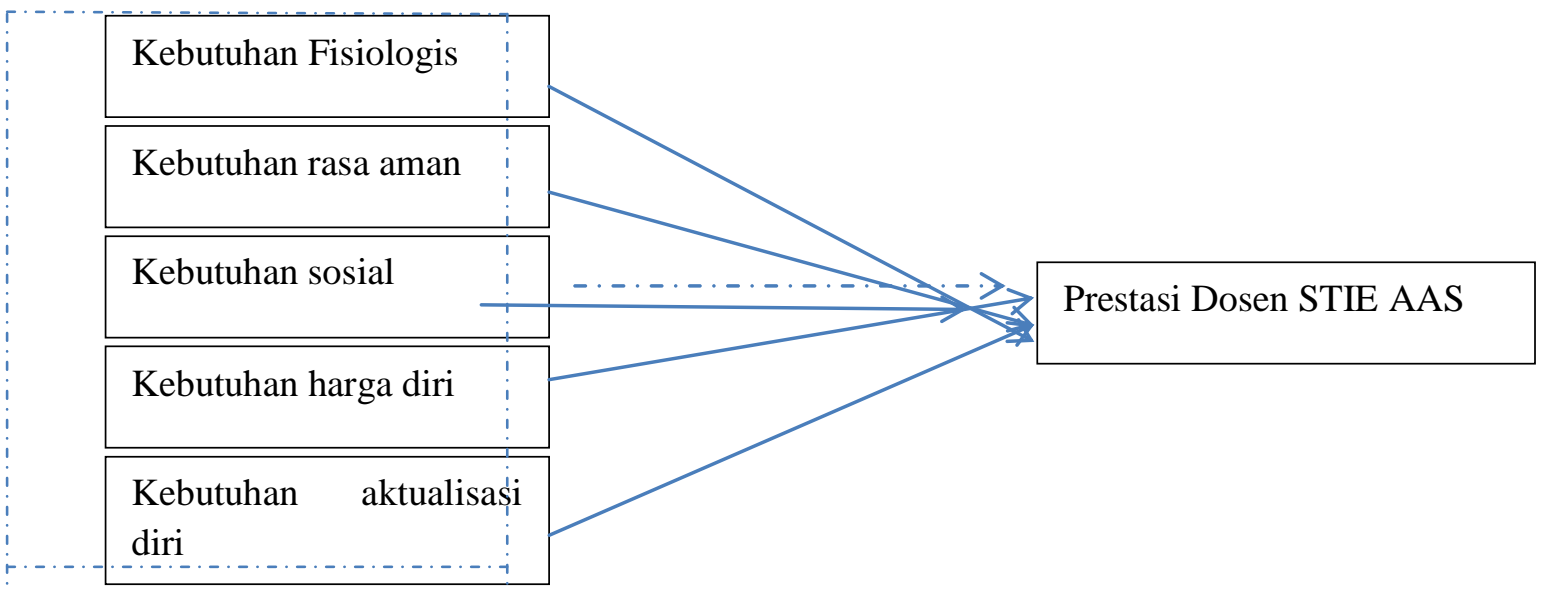

\section{Metode Penelitian}

Penelitian tentang pengaruh motivasi kerja terhadap prestasi kerja dosen pada Sekolah Tinggi Ilmu Ekonomi AAS (STIE-AAS) menggunakan metode penelitian deskriptif kuantitatif.

Variabel yang digunakan dalam penelitian ini adalah variabel dependen dan variabel independen dengan rincian sebagai berikut:

\section{Variabel Dependen}

Variabel dependen pada penelitian ini adalah prestasi kerja dosen STIE-AAS. Prestasi kerja dosen STIE-AAS adalah hasil kerja yang telah dicapai setiap dosen berdasarkan penilaian tertentu sehingga mendukung keberhasilan STIE-AAS dalam mencapai tujuan. Indikator yang digunakan adalah: (1)Tanggung jawab (2) Kerjasama (3) Ketaatan (4)Pemahaman atas tugas pekerjaan

\section{Variabel Independen}

Motivasi kerja adalah keseluruhan penggerak dari setiap dosen yang dapat mengarahkan sikap dan perilaku dosen untuk bekerja lebih baik sesuai tujuan Institusi STIEAAS. Adapun pengukura motivasi kerja dalam penelitian ini didasarkan pada tingkat kebutuhan manusia menurut Maslow yaitu kebutuhan fisiologis, kebutuhan rasa aman, kebutuhan sosial, kebutuhan harga diri,dan kebutuhan aktualisasi diri.

Adapun populasi dalam penelitian ini adalah dosen STIE-AAS yang aktif mengikuti kegiatan mengajar pada saat penelitian ini dilakukan. Populasi penelitian ini sebanyak 30 dosen. Penelitian dilaksanakan di semester genap tahun akademik 2015/2016 bulan MaretApril 2016.

Teknik penentuan sampel dalam penelitian ini adalah dengan menggunakan purposive sampling. Kriteria dipilihnya populasi menjadi sampel dalam penelitian ini adalah : dosen STIE-AAS yang pada semester genap tahun akademik 2015/2016 aktif mengajar. Jumlah sampel dalam penelitian ini sebanyak 30 dosen. 
Jenis instrument yang digunakan dalam penelitian ini, yaitu: angket atau kuesioner dan dokumentasi.

Untuk menguji apakah daftar angket yang dibuat berdasarkan indikator-indikator yang ada dalam tiap variabel penelitian, baik variabel bebas maupun variabel terikat, sahih (valid) dan andal (reliabel) maka digunakan dua alat uji yaitu uji validitas dan uji reliabilitas.

Tehnik analisa data yang digunakan dalam penelitian ini adalah:

\section{Analisa Regresi Berganda}

Analisa regresi berganda digunakan untuk mengetahui pengaruh variabel bebas (kebutuhan fisiologis, kebutuhan rasa aman, kebutuhan sosial, kebutuhan harga diri,dan kebutuhan aktualisasi diri) terhadap variabel terikatnya (prestasi kerja dosen STIEAAS) secara bersama-sama dan secara parsial. Dalam penelitian ini persamaan regresi bergandanya adalah:

$Y=a+b_{1} X_{1}+b_{2} X_{2}+b_{3} X_{3}+b_{4} X_{4}+$ $\mathrm{b}_{5} \mathrm{X}_{5}+\mathrm{e}$

\section{Uji t}

Uji $t$ ini digunakan untuk menguji pengaruh masing - masing variabel independen (kebutuhan fisiologis, kebutuhan rasa aman, kebutuhan sosial, kebutuhan harga diri,dan kebutuhan aktualisasi diri terhadap variabel dependen (prestasi kerja dosen STIEAAS).

3. Pengujian Koefisien Regresi Secara Bersama-sama (Uji F).

Uji statistik $F$ bertujuan untuk menguji pengaruh semua variabel independen atau bebas (kebutuhan fisiologis, kebutuhan rasa aman, kebutuhan sosial, kebutuhan harga diri,dan kebutuhan aktualisasi diri) secara bersama-sama terhadap variabel dependen atau terikat (prestasi kerja dosen STIE-AAS).

\section{Koefisien Determinasi (Uji $\mathbf{R}^{\mathbf{2}}$ )}

Uji ini dilakukan untuk mengetahui berapa besar pengaruh variabel independen terhadap variabel dependen.

\section{Analisis Hasil Penelitian \\ Pengujian Hipotesis}

\section{Analisis Regresi Berganda}

Dari hasil perhitungan tabel di bawah dapat disajikan dalam bentuk persamaan regresi sebagai berikut:

$\mathrm{Y}=13.019-0.093 \mathrm{X}_{1}+0.885 \mathrm{X}_{2}+0.388 \mathrm{X}_{3}$

$+1.118 \mathrm{X}_{4}-0.370 \mathrm{X}_{5}+\mathrm{e}$

Hasil persamaan regresi berganda tersebut memberikan pengertian sebagai berikut:

a. Variabel kebutuhan fisiologis $\left(\mathrm{X}_{1}\right)$ berpengaruh negatif terhadap prestasi kerja dosen STIE-AAS dengan nilai koefisien sebesar 0.093 .

b. Variabel rasa aman $\left(\mathrm{X}_{2}\right)$ berpengaruh positif terhadap prestasi kerja dosen STIE-AAS dengan nilai koefisien 0.885 .

c. Variabel kebutuhan sosial $\left(\mathrm{X}_{3}\right)$ berpengaruh positif terhadap prestasi kerja dosen STIE-AAS dengan nilai koefisien 0.388 .

d. Variabel kebutuhan harga diri $\left(X_{4}\right)$ berpengaruh positif terhadap prestasi kerja dosen STIE-AAS dengan nilai koefisien 1.118

e. Variabel kebutuhan aktualisasi diri $\left(\mathrm{X}_{5}\right)$ berpengaruh negatif terhadap prestasi kerja dosen STIE-AAS dengan nilai koefisien 0.370 .

2. Uji Signifikan Parameter Individual (Uji -t Statistik) 
a. Uji hipotesis kebutuhan fisiologis terhadap prestasi kerja dosen STIEAAS.

Dari hasil perhitungan yang $\mathrm{t}$ hitung untuk variabel kebutuhan fisiologis $\left(\mathrm{X}_{1}\right)$ sebesar -0,406 lebih kecil dari $\mathrm{t}$ tabel $(1,697)$ atau signifikasi $\mathrm{t}$ untuk variabel kebutuhan fisiologis $\left(\mathrm{X}_{1}\right)$ sebesar $0.688>\alpha(0,05)$. Hal ini berarti berarti kebutuhan fisiologis berpengaruh negative dan tidak signifikan terhadap prestasi kerja dosen STIE- AAS

b. Uji hipotesis kebutuan rasa aman terhadap prestasi kerja dosen STIEAAS.

Dari hasil perhitungan $\mathrm{t}$ hitung untuk variabel kebutuhan rasa aman $\left(\mathrm{X}_{2}\right)$ sebesar 3,330 > t tabel $(1,697)$ atau signifikasi $\mathrm{t}$ untuk variabel kebutuhan rasa aman $\left(\mathrm{X}_{2}\right)$ sebesar $0.003<\alpha$ $(0,05)$. Hal ini berarti kebutuhan rasa aman berpengaruh positif dan signifikan terhadap prestasi kerja dosen STIEAAS. Uji hipotesis kebutuhan sosial terhadap prestasi kerja dosen STIEAAS.

c. Uji hipotesis kebutuan sosial terhadap prestasi kerja dosen STIE-AAS

Dari hasil perhitungan $\mathrm{t}$ hitung untuk variabel kebutuhan sosial $\left(\mathrm{X}_{3}\right)$ sebesar $1,231<\mathrm{t}$ tabel $(1,697)$ atau signifikasi t untuk variabel kebutuhan sosial dosen $\left(\mathrm{X}_{3}\right)$ sebesar $0.230>\alpha$ $(0,05)$. Hal ini berarti kebutuhan sosial dosen berpengaruh positif dan tidak signifikan terhadap prestasi kerja dosen STIE-AASUji hipotesis kebutuhan harga diri terhadap prestasi kerja dosen STIEAAS.

d. Uji hipotesis kebutuan harga diri terhadap prestasi kerja dosen STIE-AAS
Dari hasil perhitungan yang diperoleh $t$ hitung untuk variabel kebutuhan harga diri $\left(\mathrm{X}_{4}\right)$ sebesar 4,224 $>\mathrm{t}$ tabel $(1,697)$ atau signifikasi $\mathrm{t}$ untuk variabel kebutuhan harga diri $\left(\mathrm{X}_{4}\right)$ sebesar $0.000<\alpha(0,05)$. Hal ini berarti kebutuhan harga diri berpengaruh positif dan signifikan terhadap prestasi kerja dosen STIE-AAS.

e. Uji hipotesis kebutuhan aktualisasi diri terhadap prestasi kerja dosen STIEAAS.

Dari hasil perhitungan $\mathrm{t}$ hitung untuk variabel kebutuhan aktualisasi diri $\left(\mathrm{X}_{5)}\right.$ sebesar $-1,474<\mathrm{t}$ tabel $(1,697$ atau signifikasi $\mathrm{t}$ untuk variabel kebutuhan aktualisasi diri $\left(\mathrm{X}_{5}\right)$ sebesar $0.153>\alpha$ $(0,05)$. Hal ini berarti kebutuhan aktualisasi diri berpengaruh negatif dan tidak signifikan terhadap prestasi kerja dosen STIE-AAS.

f. Dari hasil perhitungan dengan bantuan komputer, faktor motivasi yang paling kuat pengaruhnya terhadap prestasi kerja dosen STIE-AAS adalah variabel kebutuhan fisiologis dengan $\mathrm{t}$ hitung sebesar 3,494

\section{Uji F}

Dari hasil perhitungan statistik menggunakan SPSS 16, diperoleh nilai $\mathrm{F}$ hitung sebesar 11,280 dengan tingkat signifikansi 0,000 . Nilai signifikansi yang dihasilkan tersebut lebih kecil dari $\alpha .=0,05$. Hal ini berarti bahwa variabel kebutuhan fisiologis, kebutuhan rasa aman, kebutuhan sosial, kebutuhan harga diri dan kebutuhan aktualisasi diri secara simultan berpengaruh signifikan terhadap variabel prestasi kerja dosen STIE-AAS

\section{Koefisien Determinasi $\left(\mathbf{R}^{2}\right)$}

Dari hasil perhitungan dengan program SPSS dapat diketahui bahwa koefisien 
determinasi yang dapat dilihat dari Adjusted $R$ Square, diperoleh sebesar 0,639. Hal ini berarti $63,9 \%$ prestasi kerja dosen STIEAAS dapat dijelaskan oleh variabel kebutuhan fisiologis, kebutuhan rasa aman, kebutuhan social, kebutuhan harga diri dan kebutuhan aktualisasi diri. Sedangkan sisanya $36,1 \%$ dijelaskan oleh variabelvariabel lainnya yang tidak diteliti dalam penelitian ini.

\section{Pembahasan}

Hasil penelitian ini menunjukkan hanya ada dua variabel bebas yang berpengaruh signifikan terhadap prestasi kerja dosen dan tiga variabel bebas yang tidak berpengaruh signifikan terhadap prestasi kerja dosen. Dua variabel bebas yang secara parsial berpengaruh signifikan kepada prestasi kerja dosen STIE-AAS yaitu variabel kebutuhan rasa aman dan kebutuhan harga diri. Sedangka tiga variabel yang secara parsial tidak berpengaruh signifikan yaitu variabel kebutuhan fisiologis, variabel kebutuhan sosial dan variabel kebutuhan aktualisasi diri. Sedangkan penelitian Rusdiyanto (2012) menyatakan ada tiga variabel bebas yang berpengaruh pada prestasi kerja yaitu kepuasan kerja, kesempatan maju dan kebijakan organisasi berpengaruh positif dan signifikan terhadap prestasi kerja pegawai di satuan pamong praja kabupaten Tulung Agung. Sedangkan 3 variabel bebas lainnya (gaji, kondisi kerja, kerjasama) tidak berpengaruh signfikan terhadap pretasi kerja.

Hasil penelitian ini menunjukkan variabel kebutuhan rasa aman dan kebutuhan harga diri secara parsial berpengaruh signifikan terhadap prestasi kerja dosen STIE-AAS dan dari adjusted $R$ square sebesar $63,9 \%$ yang berarti prestasi kerja dosen dipengaruhi oleh faktor- faktor yang diteliti dalam penelitian ini. Penelitian ini sejalan dengan penelitian Theodora Yatipai, Jhon Montolalu, Sony Gerson Kaparang (2015) yang menyatakan ada pengaruh signifikan variabel motivasi terhadap prestasi kerja karyawan pada PT Kantor Pos Tipe C Manado dan motivasi mempunyai pengaruh sebesar $46,5 \%$ terhadap prestasi kerja karyawan dan sisanya dipengaruhi oleh factor-faktor lain yang tidak diteliti pada penelitian ini

Hasil penelitian ini menunjukkan variabel motivasi (kebutuhan rasa aman, dan kebutuhan harga diri) berpengaruh signifikan secara secara parsial dan simultan terhadap prestasi kerja dosen STIE-AAS. Hasil tersebut sejalan dengan penelitian Sindi Larasati dan Alini Gilang (2014). Hasil penelitian Sindi Larasati dan Alini Gilang menyatakan variabel motivasi ( kebutuhan prestasi, kebutuhan afiliasi, dan kebutuhan kekuasaan) secara simultan dan parsial berpengaruh signifikan terhadap kinerja karyawan dan koefisin determinasinya sebsar 0,555 .

\section{Penutup}

\section{Kesimpulan}

1. Kebutuhan fisiologis, rasa aman, sosial, harga diri dan kebutuhan aktualisasi secara simultan berpengaruh signifikan terhadap prestasi kerja dosen STIE- AAS Surakarta.

2. Kebutuhan fisiologis berpengaruh negatif dan tidak signifikan terhadap prestasi kerja dosen STIE-AAS Surakarta.

3. Kebutuhan rasa aman mahasiswa berpengaruh positif dan signifikan terhadap prestasi kerja dosen STIE-AAS Surakarta

4. Kebutuhan sosial berpengaruh positif dan tidak signifikan terhadap prestasi kerja dosen STIE-AAS Surakarta. 
5. Kebutuhan harga diri berpengaruh positif dan signifikan terhadap prestasi kerja dosen STIE-AAS Surakarta.

6. Kebutuhan aktualisasi diri berpengaruh negatif dan tidak signifikan terhadap prestasi kerja dosen STIE-AAS Surakarta.

\section{Saran}

Mengingat motivasi kerja berpengaruh positif dan signifikan terhadap prestasi kerja dosen STIE-AAS, hendaklah faktor motivasi kerja diberikan perhatian yang lebih oleh Pimpinan STIE-AAS beserta jajaran manajemennya . Pemberian motivasi kerja bisa diberikan melalui pemberian dukungan dan kepedulian terhadap keinginan dan kebutuhan dosen STIE-AAS. Misalnya memberikan berbagai fasilitas untuk mendapatkan sertifikasi dosen, meningkatkan kesejahteraan para dosen, melengkapi sarana dan prasana untk kegiatan belajar mengajar.

\section{Daftar Pustaka}

Ahmad S Ruky. 2002. Sistim Manajemen Kinerja. Pt Gramedia Pustaka Utama. Jakarta

Adi Supriyanto, 2003. Manajemen Pendidikan. Malang: Universitas Negeri Malang

As'ad, Moh. Drs., S.U., Psi,. 1995. Seri Ilmu Sumber Daya Manusia, Psikologi Industri. Edisi 4. Liberty. Yogyakarta,

Bernadin and Ruseel, 1993. Human Resources Management. New Yersey: International Edition Upper Saddle, Prantice Hall

Ghozali, Imam. 2011. Aplikasi Naiss Multivariate DengaProgram IBM SPSS 19 (edisi ke lima) Semarang: Universitas Diponegoro

Gomes, Faustino Cardoso, 2003. Manajemen Sumber Daya Manusia, Penerbit Andi, Jogjakarta
Hasibuan, Malayu S.P. 2002. Manajemen Sumber Daya Manusia. Bumi Aksara. Jakarta

H. Hadari Nawawi, 2003. Manajemen Sumber Daya Manusia Untuk Bisnis Yang Kompetitif, Cetakan Ke - 7, Gadjah Mada University Press, Yogyakarya

Hersey, Paul dan Ken Blanchard. 1992. Manajemen Perilaku Organisasi : Pendayagunaan Sumberdaya Manusia, Cetakan Ketiga, Alih Bahasa Agus Dharma, Erlangga, Jakarta.

Jewell, L. N. \& Siegall, M.. 1998. Psikologi Industri/Organisasi Modern: Psikologi Penerapan Untuk Memecahkan Berbagai Masalah Di Tempat Kerja, Perusahaan, Industri, Dan Organisasi, ed-2, Jakarta: Arcan

Koswara E.1991. Teori-Teori Kepribadian. Bandung: PT Eresco

Larasati, Sindi dan Ani Gilang. Pengaruh Motivasi Kerja Terhadap KINERJA Karyawan Wilayah Telkom Jawa Barat Utara (Witel Bekasi). Jurnal Manajemen Organisasi. Vol. V, No. 3. Desember 2014. Bandung Universitas Telkom Bandung

Robbins, Stephen P. 2001. Perilaku Organisasi Edisi ke-8. PT. Prehalindo. Jakarta.

Rusdianto. Pengaruh Motivasi Kerja Pegawai di Satuan Polisi Pamong Praja Kabupaten Tulung Agung Indonesi, Jurnal "OTONOMI" Volume 12 Nomor 2. April 2012

Sarjono, Hadi dan Juliani, Winda. 2011. SPSS vs LISREL: Sebuah Pengantar, Aplikasi untuk Riset. Jakarta: Salemba Empat

Sekaran, Uma, 2006. Metodologi Penelitian Untuk Bisnis, Jakarta: Salemba Empat

Theodora Yatipai, John Montolalu dan Sonny Gerson Kaparang. Pengaruh Motivasi Terhadap Prestasi Kerja Karyawan Studi Pada PT Pos Indonesia Tipe C Manado. Jurnal Administrasi Bisnis 2015

Usman Uzer, M. 2006. Menjadi Guru Profesional. Bandung: PT Rempa Rosdakarya 